\title{
JATISABA (2015) AND ELEVEN MINUTES (2003) FROM A PSYCHOANALYTIC FEMINIST PERSPECTIVE: A COMPARATIVE STUDY
}

\author{
Rizki Eka Putri Alda \\ Universitas Gadjah Mada, Indonesia \\ Email: putrialda20rizki@gmail.com
}

\begin{abstract}
This study analyzes Jatisaba, a novel by Ramayda Akmal and Eleven Minutes, a novel by Paulo Coelho, within a comparative literature framework. It aims to compare the transformation of the main female characters and their struggle to survive in both novels. By means of a descriptive qualitative method, the research was conducted from a psychoanalytic feminist perspective. This perspective believes that women are not born inferior, but some factors in her life have been placing them in an inferior position to men. The study resulted in the following findings. First, the main characters of both novels, Mae and Maria, underwent a psychological transformation throughout their life journeys of surviving human trafficking, sexual harassment and prostitution and navigating their love lives Both of them were brought up by a mother with a strong character that could protect them from castration and gender inferiority as a woman. Second, Mae and Maria's struggle to survive became the cause of their resistance against patriarchal values with the power of their femininity. Third, the difference between the endings of the two novels reflects the different social and cultural values in the respective stories that greatly influence the female characters' lives.
\end{abstract}

Keywords: Characterization, comparative literature, femininity, psychoanalytic feminism, resistance

\begin{abstract}
ABSTRAK
Penelitian ini bertujuan untuk menganalisa novel Jatisaba karya Ramayda Akmal dari Indonesia dan Eleven Minutes karya Paulo Coelho dari Brazil menggunakan pendekatan sastra banding. Penelitian ini mengungkap transformasi karakter dari tokoh utama perempuan dalam kedua novel dan cara mereka bertahan hidup dalam dunia yang didominasi oleh budaya patriarki. Penelitian ini menggunakan metode deskriptif kualitatif dan perspektif feminis psikoanalisis. Perspektif ini berpandangan bahwa perempuan tidak dilahirkan sebagai makhluk inferior, tetapi ada beberapa faktor dalam hidup mereka yang dapat menyebabkan mereka berada pada posisi inferior. Hasil penelitian mengungkap tiga hal berikut ini. Pertama, transformasi psikologis dari tokoh utama perempuan dalam kedua novel, Mae dan Maria, merupakan hasil dari perjalanan hidup mereka melalui pengalaman-pengalaman seperti perdagangan manusia, kekerasan seksual dan prostitusi serta kehidupan percintaan. Keduanya dibesarkan oleh sosok ibu yang tangguh yang melindungi mereka dari kastrasi dan inferioritas sebagai perempuan. Kedua, perjuangan untuk bertahan hidup yang ditunjukkan Maria dan Mae menggambarkan perlawanan terhadap nilai-nilai patriarki menggunakan femininitas mereka Ketiga, pengaruh faktor-faktor sosial dan budaya terhadap pembentukan karakter kedua tokoh utama tersebut tercermin dalam akhir cerita yang berbeda antara novel Jatisaba dan Eleven Minutes.
\end{abstract}

Keywords: Karakterisasi, sastra bandingan, feminitas, feminism psikoanalisis, resistensi 


\section{INTRODUCTION}

Women's struggle to survive is one of interesting topics of discussion because in many cases it brings attention to the importance of women's fight for freedom from oppression and equal rights especially for women whose way of living is considered undignified in the society, such as those who decide to earn a living as a prostitute (Azumurana, 2016).

The novel Eleven Minutes (2003), a book written by Paulo Coelho, is one of the novels that is brave enough to raise such issues. Eleven Minutes tells the story of a woman named Maria who is a victim of human trafficking. In order to survive, this character finally chooses to live as a prostitute. Another character which suffers a similar fate is Mae in the novel titled Jatisaba (2016) written by Ramayda Akmal. Mae is also a victim of human trafficking, and for the sake of her own life, Mae is willing to do anything. Mae is involved in human trafficking under the guise of a foreign labor recruiter. Not only does Mae work as a recruiter, she also does sexual favors for her boss. In fact, she frequently uses her femininity to get all her jobs done. Apart from these similarities, there are differences in the ways the two novels represent women's struggles in coping with harsh realities. One contributing factor in these differences is the authors' cultural backgrounds. The unique similarities and differences of the novels are worth comparing in relation to this factor.

The present study focuses on how the image of women in society is depicted in the stories in Jatisaba and Eleven Minutes and how the female characters' struggles to achieve freedom are narrated in these novels. To better understand the aspects of women's struggle and the issue of inequality in the novels, psychoanalytic feminist theory is employed in the analysis of the abovementioned subject of discussion. The theory seeks to provide fundamental explanations of the ways women react as affected by their psyche and their ways of thinking (Tong, 2014: 190).

In the 1970s feminist perspective was largely influenced by Sigmund Freud's psychoanalytic theory of sexuality and subjectivity (Brooks, 2011: 104). Freud developed a theory of gender acquisition as the key to recognize the concept of gendered subjectivity. Freud states that feminine and masculine subjectivities are based on the 'psychic structure' of sexual identity that were acquired during the early years of childhood. Based on this assumption, women's inferiority is the result of the Oedipus complex and castration that women have experienced when they accepted themselves as 'the other' and the inferior individual because they did not have penis like boys, which is called as "Penis envy" (Zepf \& Seel, 2016: 397-398).

Sigmund Freud's concept of gender identity is in contrast to feminist views because it "amount[s] to an attestation that one portion of humankind is malcontented with the sex doled out to it," and that it "is determinedly uninspiring, not exclusively to women yet in addition to biological science"(Balsam, 2013: 695). Feminists believe that there is little possibility of the connection between women's biological condition and their position in society or their disempowerment by men. The problem is that this possibility of connection is created or constructed by the society itself (Tong, 2014: 196).

Karen Horney argues that the inferior feeling experienced by women has its root not in their castration, the awareness of their social subordination. Patriarchal system compels women to believe that they are feminine (passive, masochistic, narcissistic) and that being feminine is acceptable whereas showing masculinity is abnormal (in Nugroho, 2019: 150)"me ndeley":\{"formattedCitation":"(Nugroho, 2019.

To counter such system, feminists take the stance that women and men are equal. Women's abilities are not inferior to men's, but patriarchal culture greatly reduces their chance to prove them. It makes men look superior and luckier for being born into a gender with penis. Feminist psychoanalysis counters this perspective by promoting the notion of androgynous society that is built on the combination of feminine and masculine characteristics (Tong, 2014: 196-7).

In addition to using feminist theory, the researcher also uses comparative literary approach to examine the two novels. Comparative literature or la litterature comparee is the only literary science that does not produce a theory (Damono, 2009: 1-2). Comparative literature is an investigation of literary texts written in different languages for their underlying linguistic, literary and cultural significances as they are put into perspective with one another (Sahin, 2016: 5). According to Wellek and Warren, "comparative literature" as a study of relationships between two or more literatures (Wellek \& Warren, 2014: 40).

Comparative literature is a key that opens all entryways across national, cultural, linguistic, 
historical, social or political boundaries. When we turn our consideration to world writing, we perceive echoes of masterpieces of our literature and other countries' literatures as translations and imitations, frequently by second-rate authors, or the prehistory of masterpieces, the movements and the spread of their topics and structures (Hart, 2011: $16 \& 31$ ).

Comparative study needs a vivid perspective approach to obtain the best result of the comparative analysis process. Comparative approach compares two or more literary works from different countries. The reputation of the writers can be seen in this comparative process too. In this context, the translated literary works and the activities of exporting and importing books have become a big field of comparative study. All of these activities work together to create the identity and the concept of comparative literature. This field of study enables styles of writing, concepts from different areas and authors to be distinguished easily (Brown, 2013: 67).

Before proceeding to the analysis section, the researcher would like to discuss a number of previous studies that present an exploration about Jatisaba and Eleven Minutes. This literature review is intended to inform the readers about the area that researcher wishes to contribute to in comparison with the existing studies. It is also a way to ensure that the present research does not repeat the same topic or analysis and to avoid plagiarism in research papers (Snyder, 2019: 334).

The first is a study by P. A. Jothi titled "Exploring the Soul of Maria in Paulo Coelho's Eleven Minutes" (2019). Jothi attempts to present a new perspective on Coelho's Eleven Minutes, particularly in relation to sex and women. His study finds that Eleven Minutes offers a different observation about the life of a prostitute. Coelho draws attention to the topic of sex in prostitution and in relationship where sex and affection are not equally meaningful. Through Maria, Coelho portrays the contrast between sex adventure and love expression and questions the different grounds of cultural codes of a profound quality and honorable living (Jothi, 2019: 82-85).

The second study is "Human Ethos of Paulo Coelho's Selected Novels: A Critico-Thematic Analysis" by Mirafuentes, Alegria, Chua, and Arcipe (2015). The research focuses on human ethos in several literary works written by Paulo Coelho including Eleven Minutes. This study discovers that these works depict the strict excursion that the characters go through and how it signifies a journey towards selfcompletion through otherworldly illumination and dream-acknowledgment. In this way, Coelho conveys that a man will be able to achieve his destiny when he has contributed something to the world that affect changes (Mirafuentes, Alegria, Chua, \& Arcipe, 2015: $171 \& 187)$.

The third study, "Estetika Dalam Novel Jatisaba Karya Ramayda Akmal," was written by Sugiarti (2016). She analyzes the aesthetic essence of Jatisaba by Ramadya Akmal using stylistic approach. The study shows that the aesthetic code of the novel is characterized by its unique use of language as an aesthetic tool. The author's choice of language style is able to reveal the empirical experience of the characters in the story (Sugiarti, 2016: 100).

The forth study is A. Zamuri's "Membaca Jatisaba: Menelisik Memori, Trauma, dan Jalan Pulang." It describes the construction of memory and trauma in Ramayda Akmal's Jatisaba using memory and trauma perspectives. The data found that the memory constructed in the novel relates to the traumatic memory of Mae who lost her home and the traumatic events when she worked as an Indonesian migrant worker abroad. With her sense of loss and traumatic memories, Mae became a traumatic subject (melancholia). Zamuri concludes that the memory reconstruction in the novel is actually the author's way to go back to Jatisaba, a place where his family once lived (Zamzuri, 2020: 270 \& 281).

The similarities of all the above-mentioned studies are that they focus on the main character and include a linguistic viewpoint in discussing the story in the novel under study. Another similarity that make them different from the research presented in this article is that none of them use psychoanalytic feminist theory and comparative literary approach. The present study is intended to be an important and useful contribution because topics related to issues of feminist concern are still relevant for a large audience, especially those issues that women still struggle with. Comparative literary studies can be a medium to spread awareness and deeper understanding of the importance of gender equality and the ways society treats and positions women in various domains in different cultures for the purpose of exploring the right ways to support women's fight for equality more broadly. 
As mentioned earlier, this article offers a comparative literary study of Ramayda Akmal's Jatisaba and Paulo Coelho's Eleven Minutes with descriptive qualitative method of analysis. The primary data for this research are the literary texts of Jatisaba (2016) and Eleven Minutes (2003). The secondary data are taken from books containing information and insights that can support the analysis of the primary data.

This study uses library research method and note-taking technique to collect the data. The researcher begins the process by reading the texts of both novels and understanding all the sentences in them, then identifying how the female main characters are characterized in the stories. Afterwards, the researcher examines how both characters' struggles for freedom are depicted in the stories, and then interprets them from psychoanalytic feminist perspective. The next step is comparing the two cases (Mae and Maria) and describing how they are similar with and different from each other for which psychoanalytic feminist theory and some relevant references are employed to support the interpretation in the analysis.

\section{FINDINGS AND DISCUSSION}

\section{The sense of castration for being born as a woman}

The analysis of the characterizations of Mae in Jatisaba and Maria in Eleven Minutes starts from their childhood as the early stage of their development. At this stage, the characterizations of Mae and Maria portray their transformation in two parts. The first part is when Mae and Maria recognize their family condition and realize who they are in the family. The second one is when they position themselves in their relationship with boys. This stage is important because it is associated with the issue of girlhood as an obstacle to survival or a soul changing experience to go through while in truth it is an issue of understanding the constructions and relations that implicate a girl in her own division and alienation (Mitchell, 2017: 271).

Both Mae and Maria are from middle class families. They are unaware of the socioeconomic status of their family. Contrary to Freud's theory of personality development, the characterizations of Mae and Maria show that they do not perceive themselves as entirely feminine. In Jatisaba, Mae sees her mother as a stronger figure than her father. Mae does not feel that her mother is inferior to her father. She doesn't feel inferior because she grows up with the values that her mother instils into her as a strong figure in the family.

"I remembered the last time I came home. Mother was caught in the euphoria of her euphorbias. Every morning, she would caress her euphorbias instead of preparing breakfast for us. But because we were so used missing meals, we didn't find it strange. We did get upset when we thought that Mother had lost her battle with depression. Talking to her flowers. Only later did we realize that it all had purpose. Mother had so many flowers, of all shapes and sizes, and I had to admit they were beautiful. Some people agreed and bought them. Mother could pay the electric bill. Buy milk for brothers and cigarettes for father" (Akmal, 2015: 20).

In comparison with Mae, both of Maria's parents work. It is described in the novel that "Her father was a travelling salesman, her mother a seamstress, and her hometown, in the interior of Brazil [...]" (Coelho, 2003: 1). She grows up in a balanced family life with little conflict, and she learns the values of life from both of her parents. Unlike Mae, Maria mostly learns the values of life from her mother. Her mother always teaches her not to waste her time while she is still young, especially because she is a woman: "[...] there was one thing her mother said that she never forgot: 'Beauty, my dear, doesn't last" (Coelho, 2003: 17).

It can be seen that the portrayals of Mae and Maria's childhood experiences in the two novels do not support Freud's theory about gender and women's sense of inferiority. One of the reasons is that every person has his/her own problem. As what Alfred Adler states, there is no guarantee that the person who has penis will be endowed with "superiority" because one's biological anatomy cannot be avoided and therefore cannot be associated with certain psychological characterization (in Tong, 2014: 201).

In Mae's case, her mother has more power because her father is too lazy to take on his responsibilities although he lives in a society in which father should be the leader of his family. Mae recalls, "I vividly remembered how one year Father had made an enormous daplangan kite with five tails, each 30 
meters long. Sadly, it was too tail-heavy to fly" (Akmal, 2015: 38). This quotation reflects how her father is not someone she can rely on. As a result, Mae looks up to her mother more than to him, and she grows up by her mother's values instead of her father's. She grows up to be a woman who has the courage to take chances and make sacrifices like what her mother had done for her family.

In Eleven Minutes, Maria's family condition does not contribute much to her characterization, but her social environment does. Maria is always curious about new things because there are many questions in her mind about what happen outside her small village: "[...], which was why Maria was always hoping that one day, without warning, her Princes Charming would arrive, sweep her off her feet and take her away with him so that they could conquer the world together" (Coelho, 2003: 1).

Maria's dream of meeting a "prince" as an innocent little girl signifies her curiosity of the outside world. Beauvoir describes that in a more or less disguised way, her youth is consumed by waiting. She is waiting for a man (Beauvoir, 2010: 395). However, this wishful thinking doesn't last too long. After experiencing several heartbreaks in her relationships with boys, she finally learns that the reality is not as beautiful as her imagination about them.

With her experiences with boys, she finally learns that they do not always bring happiness like what she was dreaming about in the past. She finds that the reality is not like what she ever imagined. As she grows up, Maria understands more about the complexity of having a relationship with the guy that makes her tougher.

"With each day that passes, I see more clearly how fragile men are, how inconstant, insecure and surprising they are ... a few of my girlfriends' father have propositioned me, but I've always refused. At first, I was shocked, but now I think it's just the way men are" (Coelho, 2003: 16).

In contrast with Maria who experiences heartbreaks and sees the mistaken belief of man's superiority, Mae has good memories of friendship and love when she was an adolescent. Besides her family, Mae also has friends to play with and gets to know about love in her relationship with a boy named Gao.

"Back then, after we'd play cina boi in the pereng, I'd often wash myself here at Kusi's well. Gao would often be coming back from fields, sack of rice on his back, around this time. He liked to wash his feet here too. He'd fetch the water for me. Sometime he'd even wait for me finish. Since the first time that happened, the shower at Kusi's was more important to me than playing cina boi. So I'd play with as much enthusiasm as I could. I made sure I got dirty. I made sure I fell into the ditch. That meant I could bathe at Kusi's place" (Akmal, 2015: 200).

Mae does everything she can to be with Gao, and it is almost like what Maria does to impress a guy. However, for Gao, his encounters with Mae are just brief moments of happiness. The ways Mae and Maria treat boys represent a woman who think that the man she cares about gives all his attention only to her while for him she is just one nice moment that is not special enough to distract him from his daily activities.

Mae's sexual desire and sexual interpretation are stronger than her rational mind that she does not realize and accept the reality properly. Mae thinks that all men are like Gao. In Jatisaba there are some parts describing how sometimes Mae feels sensual when she imagines certain parts of men's body as well as men's posture and gesture, and all of these remind her of Gao.

"I'd like to see. Can I Come?"

"Ayuh, Bungah malah nyong, dikancani wedon moblong, hehe (Come on! I'm always happy to have a beautiful woman by my side!)."

"I tailed behind them. The young men in my village often went out and about without shirts on" (Akmal, 2015: 74).

"In my imagination, one of these young men had eyes like an eagle. He could draw the fish to the surface with just his eyes. I smiled to myself..." (Akmal, 2015: 75).

Mae always feel nostalgic about her beautiful past and gets carried away whenever she is in Jatisaba. It is because she suffers from trauma. As Zamzuri explains, Mae has melancholia (Zamzuri, 2020). This situation makes Mae want to feel what she used to feel in the past even though she knows everything has changed. Her unconscious still refuses to accept the reality. This is also the problem that will eventually blur Mae's focus on her mission.

While Mae still dreams about men's superiority 
because of her beautiful past with Gao, Maria becomes more mature and wiser from her journey of discovering many things in her life. The first thing she discovers is the different facts about masturbation and making love. She feels that masturbation is more joyful than sexual intercourse: "Unlike masturbation, which took her up to heaven, this hurt her and caused a trickle of blood which left a stain on her skirt that took ages to was out" (Coelho, 2003: 15).

The description of Maria's satisfaction with masturbation more than sexual intercourse can be seen as a symbolic representation of the fact that women do not always need penis or feel shameful/ inferior for not having it. Thus, Maria's sexual experience of enjoying masturbation much more than sexual intercourse here can be understood as a sign that she does not experience a "penis envy." She is proud of having her sexual organ, especially the clitoris. She does not feel shameful and does not feel castrated.

As mentioned earlier, there is a tendency in society for man to control woman and to not care about what the woman feels in bed with him because of the perception that women have to please men. Also, women are expected to protect their husbands' honor throughout their marriage life and if they fail to do so, they will be condemned by the society as an immoral woman or a slut (Reineke, 2017: 33). However, in Maria's case, she does not care about the social norms, and she even takes control of her relationship with her partner.

"She made love with the same boy a few more times, although she had to threaten him first, saying that if he didn't, she would tell her father he had raped her. She used him as a way of learning, trying in every way she could to understand what pleasure there was in having sex with a partner" (Coelho, 2003: 15).

\section{The Superiority of Femininity}

Both in Jatisaba and Eleven Minutes, the main characters have the horrible experience of becoming the victim of human trafficking. Mae in Jatisaba becomes the victim of human trafficking and is forced to work as a prostitute under Mr. Kim's control, whereas Maria is tricked by her boss into working much longer hours with less salary. Later, Maria is fired, which leads her to prostitution as she needs to earn some money.
Mae in Jatisaba does not work as a prostitute like Maria does, but she can be seen as a prostitute too. As we know that the definition of a prostitute is a person who has sex with someone for money. In addition, based on Oxford Dictionary, prostitute is "a person, in particular a woman, who engages in sexual activity for payment" (Oxford Dictionary, 2021). Following these definitions, prostitute can be construed as someone who gets payment for serving his or her customer sexual activity; the payment can be money, certain benefits, gifts or special treatments according to the agreement between the and the client. Even though Mae does not literally work as a prostitute who sells her body for money, she sometimes does sexual activity to save her life such as when she needs the Old Major's protection from Mr. Kim and also from the risk of being expelled: "The sweet of lust. The sweat of guilt. The sweat of sin. All blending together. For years the Old Major and I had spread such a sweat all over his mattress as Cik Vicky went shopping" (Akmal, 2015: 162).

The dreadful feeling of being a human trafficking victim makes Mae learn that she can use her body, her femininity, for her own benefit despite the fact that most people think that femininity is the factor that makes women inferior to men. She learns how the world around her works. While Mae finally learns about the reality of life after she experiences human trafficking, Maria has already learned to use her "femininity" since she was in Rio. Maria was once a shop assistant there. She makes use of all her experiences with men and her femininity to get more money from her boss. As narrated in Eleven Minutes, "Maria knew how to use a man, without being used by him. She never let him touch her, although she was always very coquettish, conscious of the power of her beauty" (Coelho, 2003: 17). One of the major reasons for Maria and Mae's choice of living their life this way is that they need to survive and cope with challenges as the result of being tricked by their agents. The only thing that they think they can do is to be a prostitute, using their femininity.

"There are women who make of themselves a nosegay, an aviary; there are others who are museums, still others who are hieroglyphics" (Evans, 2013: 196). We can see the representation of this statement in Mae's and Maria's situations. Being a prostitute is not Maria and Mae's first choice. They are both "a normal person mentally and physically" (Beauvoir, 
2010: 681). One thing that they have in common is that they believe that they have to struggle to survive. Moreover, being a woman is not a big problem for them. In this context, Mae and Maria's situation signifies a superiority in the form of femininity.

Nonetheless, being a prostitute does not mean that Mae and Maria have no feeling. In Maria's case, she does not believe about love the way she ever did before because she has always failed to keep a romantic relationship with a man. Because of her failures in this regard, she thinks that love is not for her. Unlike Maria, Mae still believes in love. Although she works abroad, her feeling for Gao does not fade away. When she returns to Jatisaba, one of the first things that immediately comes to her mind is him.

"By God, after travelling to all those cities, you still think of that shepherd. That grass harvester. Gao's got a family now. Sometime he still looks for grass here. He's got three kids!" (Akmal, 2015: 44).

There are different opinions for different contexts concerning the two women's relations with their customers as a prostitute. It is frequently stressed that she reserves kissing on the lips, the declaration of genuine delicacy, for her genuine romance (Beauvoir, 2010: 688). This is the kind of feeling that Mae has for Gao. The words "the lips" in the above expression symbolize such feeling.

One of the aspects that makes Mae and Maria are different from each other in their journeys is their ways of thinking. Mae in Jatisaba does not want to accept the reality that her old boyfriend has already had a wife and children, and so she cannot find any solution for her situation. In contrast, in Eleven Minutes, Ralf Hart the artist, the man that Maria is seeing, knows that Maria works at a night club as a prostitute. He says: "This has nothing to do with you as prostitute, but with you as woman" (Coelho, 2003: 114). After her acquaintance with Hart, Maria realizes about her mistake of misunderstanding him for the first time, and she is finally able to forgive him.

Even though Maria loves Hart, she doesn't not easily fall for him because after all she has been through she will not see men as a superior gender anymore. Maria still sticks to her plan to make a lot of money and go home to build a new beginning for a happy life for herself. She is not afraid of losing Hart because she is more realistic than she ever was before.
"And if that is what happens, if I have already lost him, I will at least have gained one very happy day in my life. Considering the way the world is, one happy day is almost a miracle" (Coelho, 2003: 123).

A good relationship requires understanding of the partner's character that include his/her weaknesses, the mistakes he/she has made and his/her imperfection (Paulo, 2015: 6). In Maria's relationship with Hart, this kind of understanding is represented in Hart's acceptance of Maria as she is despite her occupation. They only talk and share their stories to get to know more about each other. A couple who have a good relationship do not only care about sex in their interactions, but it does not mean that they do not want it. It is just because their emotional feeling of love is bigger than their desire of sex (Paulo, 2015, 4).

Even though Maria already found Hart, she still sticks to her plan. On the contrary, Mae still loves Gao, but she could not have him. Between love and sex, Mae can only fulfill her desire, but not her need for love. Mae has a partner named Malim. Mae knows that Malim loves her, and sometimes Malim uses Mae to please his desire. Mae knows what Malim want from her, but she never refuses him because she also has desire to satisfy. In Mae's point of view, it seems like she is in an inferior position for letting him use her body, her femininity, but the truth is Mae uses him too. Mae cannot be simply seen as a victim or the inferior one because in this situation she expresses her power covertly.

"If I did love Malim, perhaps our relationship would be about more than quenching our thirst. Maybe there'd be joy, or even ecstasy. Sadly, I'd never felt beauty of joy with him" (Akmal, 2015: 79).

Consequently, Mae's and Maria's relationships with their respective partners lead to different endings. Mae in Jatisaba and Maria in Eleven Minutes face different situations because they have different points of view based on their experiences. Mae still does not want to let go of her beautiful memories of her childhood when she was with Gao even though the reality is different now. She does not get the love that she has been dreaming of. The only thing she can do in terms of relationship with a man is please her sexual desire. Maria acts wiser than Mae as she tries to accept the reality so as to not make the memories 
of her past life haunt her anymore. As the result, she enjoys a healthy relationship with Hart, and at the same time, her sexual desire is fulfilled too.

\section{The Struggle of Women Victims of Human Trafficking}

In Jatisaba and Eleven Minutes, Mae and Maria's life stories respectively show that the experiences that they have been through affect their personality development, especially in the part where they tend to look powerless or inferior as a woman. In Jatisaba, Mae plans to get herself free with the help of the Old Major, while in Eleven Minutes Maria has to get involved in prostitution.

To make her plan work, Mae uses her femininity as a strategy even though her work needs her skill more than her femininity. When there is a problem during her mission, Mae flirts with Malim as a sign that she needs him to solve her problem because she know he loves her: "Malim, I miss you". That was the only way I could get him to comeback so soon without holding it against me" (Akmal, 2015: 135).

However, while Mae is working on her mission, she is being distracted by her feeling for her old village and Gao. This distraction makes her lose her focus, and she is late to realize that Jatisaba is a village that is full of conflicts and complexities. At the end, when Mae leaves Jatisaba, she is arrested by the police because her old neighbor, Sitas, reports her to the Police: "My suspicion had been right. I'd been sleeping in the bandit's nest. Letting her sharpen her blade so that she could stab me in the back when I least expected it. Sitas, your action have cemented my fate" (Akmal, 2015: 243).

Different from Mae who has to come back to her home village to plan her own freedom, Maria has to struggle to survive in Switzerland. She doesn't want to come back home penniless, and she still wants to explore Switzerland. Even though Maria is good at her job, she keeps improving her skill by attending to her clients' needs and conditions, and later finds that pleasing others with sex is not the only service she can give. As a result, her efforts bring a big reward.

"When she realised that realizing in the soul could be as lucrative as realizing tension in the body, she started going to the library again.. She read studies of human emotion, because all her clients were in some kind of emotion pain. Maria was a respectable, rather unusual prostitute, and after six months, she had acquired a large, faithful, very select clientele" (Coelho, 2003: 88).

Maria becomes more matured and wiser because she already knows the fact that men are not that superior. They are still human beings who have weaknesses. When she meets Ralf Hart, their acquaintance grows into a good relationship with him because Hart is an open-minded person and does not see Maria as an object even though he knows that Maria works as a prostitute: "He's seeing my soul, my fears, my fragility, my inability, to deal with a world which I pretend to master, but about which I know nothing" (Coelho, 2003: 108). As Beauvoir stated, "women as independent will no more feel ashamed on her femininity, nor does she lose her sexual attraction" (2010: 819). Hart makes her feel comfortable because with him she does not feel inferior, and their relationship is healthy and matured. She doesn't even feel attracted to Hart because of his wealth and great carrier. Their relationship is not just about sex. As explained by Jothi, Eleven Minutes show us a different portrayal of the relationship between women and sex. Even though Maria is a prostitute, that does not mean that the sex she does can satisfy her desire as a woman, and that does not mean that attraction between opposite sexes should be based on sex alone either (Jothi, 2019).

As Beauvoir suggested, there will be no more gender status when both man and woman surrender to each other: "As for me, I am, a woman who takes" (Beauvoir, 2010: 822). So it can be interpreted that Maria as a woman still behave femininely, but at the same time she has strength and determination to get what she wants that are comparable to men's. Maria's character shows a combination of femininity and masculinity. This characterization concurs with psychoanalytic feminist vision of androgynous society, which is the character of the society that combines femininity and masculinity (Tong, 2014: 190).

Both Mae and Maria struggle to have their own freedom, but it is Maria who succeeds in her struggle and becomes a more independent woman than Mae. Maria's character development in Eleven Minutes shows her growing independence as an individual. This finding agrees with Mirafuentes, Alegria, Chua, and Arcipe's description of Maria in their study (2015) 
that this character has a good work ethic. Maria's consistent hard work finally changes her life. Maria is capable of thinking rationally because her personality has a healthy balance of femininity and masculinity, which is also called an androgynous personality. She can keep her focus on her work and is not easily distracted. In contrast, Mae is distracted from her goal because she cannot forget her past. Mae does use her skill well, not only her femininity, to make her plan work, but her feeling distracts her from her mission. Consequently, Mae fails to accomplish her mission. She cannot get her freedom, and she cannot win Gao's love either. Mae loses everything.

\section{The Influence of Social Norms on Women's Personal Freedom}

The different endings of the stories in Jatisaba and Eleven Minutes are closely connected to the settings of the stories. Jatisaba is set in Indonesia, whereas Eleven Minutes is set in Rio, Brazil, Geneva and Switzerland. In spite of this difference, both novels tell the issue of human trafficking which Mae and Maria fall victim to. Both characters struggle to survive and deal with challenges in their life as a result of such unfortunate experience. Human trafficking is a modern slavery that has been a serious problem in both Indonesia and Brazil, and both countries have made great efforts to eradicate it. (Daud \& Sopoyono, 2019: 362) \& (Lazzarino, 2013)

As mentioned previously, the settings contribute to the different fates of Mae and Maria as well as their character development. In Eleven Minutes, Maria's life improves when she lives in Geneva, Switzerland. Switzerland is a liberal country where people have much personal freedom to decide their own future and to not being bothered or pressured by others. In Switzerland, prostitution has been legal since the 19th century. Prostitution is increasing because the demand for sexual service is increasing. Accordingly, the number of women choosing to be a prostitute to earn a living is also increasing. Switzerland legalized prostitution since the enactment of the Swiss Criminal Code in 1942. This code regulates policies that enable the issuance of permits or licenses for street prostitution and brothels and designate areas where prostitution is allowed to take place. Even in Geneva, prostitution has become one of tourist attractions (Siegenthaler, 2017: 222 \& 226).
The life in Switzerland, which is a liberal country that has legalized prostitution, makes an impact on Maria. Since living in Geneva she feels free because she can manage her own life without being bothered by anyone. She can do what she wants with her job and get enough money to support herself. Mae's condition is very different. She cannot do what she wants freely because her boss, The Old Major, controls her. So the only thing that Mae can do to survive is her job. Unfortunately, her job is a recruiter in human trafficking business, which is considered a crime in Indonesia.

Moreover, there are also social and culture values that play an influential role in the two novels and therefore affect the endings of the stories. In Jatisaba, Mae gets arrested for the crime she has committed. She fails to get what she wants because what she does in the business of human trafficking is illegal, and her illicit love affair with her partner is against social norms in Indonesia (Widyawati, 2020: 171).

Unlike in Jatisaba, in Eleven Minutes a happy ending is much more possible for the main character, Maria, because the setting is a liberal country where prostitution is legal. Maria has more authority over her life, and so her destiny depends on her own actions. There is no law against unmarried couple living together in Switzerland or Geneva (Harris \& Gassen, 2012: 448)

\section{CONCLUSION}

Drawing on the results of the above discussion, this research concludes that the transformation of Mae in Jatisaba and Maria in Eleven Minutes occurs because of these following reasons and factors. First, the character transformations in both novels contradict Sigmund Freud's idea of the sense of castration and inferiority in women. It is not absolute because not all women experience such issues. The characterizations of Mae and Maria show that these female characters do not experience them. The reason for this is that they are raised by a mother with a strong character. In short, both Mae and Maria grow up without going through Freud's sense of castration and inferiority.

The struggle to survive of the two characters as ex-human trafficking victims shows some similarities and differences. Maria in Eleven Minutes succeeds in becoming an independent and rational woman with 
perseverance. Maria still maintains her femininity when she finds Ralf Hart, a gentleman who is willing to accept her the way she is although he knows that Maria is a prostitute. Unlike Maria, Mae in Jatisaba has not been able to let go of the past. It makes her easily distracted and lose focus on her mission. In the end, Mae fails in her mission and gains. In comparison with the characterization of Mae, the characterization of Maria in Eleven Minutes represents an androgynous character as conceptualized in psychoanalytic feminism. Maria is depicted as a woman with a combination of feminine and masculine traits that help her in her struggle.

In conclusion, the sociocultural setting in which women live influence their personal development, and this idea is conveyed in the stories of Mae in Jatisaba and Maria in Eleven Minutes which end differently in this context. In this sense, Maria is superior to Mae because she manages to develop an androgynous personality that contribute much to her struggle to be a strong independent woman.

\section{REFERENCES}

Akmal, R. (2015). Akmal, Ramayda. 2015. Jatisaba. (Woodrich, Trans). Yogyakarta Gress Publisher. pdf. Yogyakarta: Gress Publisher.

Azumurana, S. O. (2016). Freud's "Penis Envy," Lacan's the "Desire to be the Other" Nigerian Feminist Aesthetics: Adimora-Ezeigbo's Children of the Eagle and Kaine Agary's Yellow-Yellow . Journal of the African Literature Association, 6(1), 151-163. https://doi.org/10.1080/21674736.2011.1169 0177

Balsam, R. (2013). Freud, females, childbirth, and dissidence: Margarete Hilferding, Karen Horney, and Otto Rank. Psychoanalytic Review, 100(5), 695-716. https://doi.org/10.1521/ prev.2013.100.5.695

Beauvoir, S. De. (2010). Second Sex. New Yor: Vintage.

Brooks, A. (2011). Postfeminism: Feminism, Cultural Theory and Cultural Form. Yogyakarta: Jalasutra.

Brown, C. (2013). What is 'Comparative' Literature? Comparative Critical Studies, 10(1), 3366. https:// doi.org/10.3366/ccs.2013.0077

Coelho, P. (2003). Eleven Minutes. Great Britain: Harper Collins.

Daud, B. S., \& Sopoyono, E. (2019). Penerapan Sanksi Pidana Terhadap Pelaku Perdagangan Manusia (Human Trafficking) di Indonesia. Jurnal Pembangunan Hukum Indonesia, 19(3), 14710. https://doi.org/10.14710/jphi.v1i3.352-365

Dictionary, O. (2021). Oxford Dictionary. Retrieved March 5, 2021, from https://www.lexico.com/ definition/prostitute

Evans, C. (2013). On Rereading Simone de Beavoir's The Second Sex After Thirty-Five Years. Women's Studies Quarterly: The Feminist Press, 41(1 \& 2), 2013. https://doi.org/10.1353/wsq.2013.0061.

Harris, B., \& Gassen, N. S. (2012). How Similar Are Cohabitation and Marriage? Legal Approaches to Cohabitation across Western Europe. Population and Development Review, 38(3), 435-467. https:// doi.org/10.1111/j.1728-4457.2012.00511.x.

Hart, J. (2011). Literature, Theory, Memory (United Sta). Palgrave Macmillan.

Jothi, P. A. (2019). Exploring the Soul of Maria in Paulo Coelho's Eleven Minutes. Shanlax International Journal of Arts, Science and Humanities, 6(1), 8285. https://doi.org/https://doi.org/10.5281/ zenodo. 2551354

Lazzarino, R. (2013). From Policies To Live Experince and Back: The Struggle for Reintegrating Returness Of Human Trafficking in Goiás State (Central West Brazil). Revista Interdisciplinar Da Mobilidade Humana, 21(4), 163-187. https://doi. org/10.1590/s1980-85852013000200009.

Mirafuentes, J. K. A., Alegria, M. A. A., Chua, L. I., \& Arcipe, N. L. (2015). Human Ethos of Paulo Coelho's selected novels: A Critico-Thematic analysis. University of the Visayas - Journal of Research: Reading and Literature, 171-188. https://doi. org/10.5281/ZENOD0.2380977.

Mitchell, E. (2017). he Girl and Simone de Beavouir's The Second Sex: Feminine Becomings. Australian Feminist Studies, 31(93), 259-275. https://doi. org/https://doi.org/10.1080/08164649.2017. 140764

Nugroho, B. A. (2019). Perlawanan Perempuan terhadap Dominasi Patriarki dalam Novel Geni Jora Karya Abidah El khalieqy Kajian Feminisme Psikoanalisis Karen Horney. Jurnal Sastra Indonesia, 8(2), 148156.

Paulo, H. J. (2015). Tattvabodha and the hierarchical necessity of Abraham Maslow. Journal of Management, Spirituality \& Religion, 1-12. https://doi.org/10.1080/14766086.2015.1076 735

Reineke, S. (2017). The Intellectual and Social Context of The Second Sex. In L. Hengehold \& B. Nancy (Eds.), A companion to simone de Beauvouir (pp. 28-36). https://doi.org/10.1002/9781118795996.ch2.

Sahin, E. (2016). On Comparative Literature. International Journal of Literature and Arts, 4(1), 5. https://doi. 
org/10.11648/j.ijla.s.2016040101.12

Sapardi Djoko, D. (2009). Sastra Bandingan. Jakarta: Editum.

Siegenthaler, E. (2017). Prostitution in Switzerland: Geneva, Lausane and Bern: The Paul Kinsie Reports For the League of Nation. Trafficking in Women (1924-1926), 2, 222-227. https://doi. org/10.18356/c5a11303-en

Snyder, H. (2019). iterature review as a research methodology: An overview guidelines. Journal of Business Research, 104, 333-339. https://doi. org/10.1016/j.jbusres.2019.07.039.

Sugiarti. (2016). Estetika Dalam Novel Jatisaba Karya Ramayda Akmal. Litera, 15(1), 100-110. https:// doi.org/https://doi.org/10.21831/ltr.v15i1.9769

Tong, R. P. (2014). Feminist Thought: A More Comprehensive Introduction, translated by
Aquarini Prayatna Prabasmoro. (Fifth Edit). Yogyakarta: Jalasutra.

Wellek, R., \& Warren, A. (2014). Teori Kesusastraan. Jakarta: Gramedia.

Widyawati, A. (2020). Criminal Policy of Adultery in Indonesia. JILS (Journal of Indonesian Legal Studies), 5(1), 171-186. https://doi.org/ https://doi.org/10.15294/jils.v5i1.36786.

Zamzuri, A. (2020). MEMBACA JATISABA: MENELISIK MEMORI, TRAUMA, DAN JALAN PULANG. Widyaparwa, 48(2), 269-282. https://doi. org/10.26499/wdprw.v48i2.629

Zepf, S., \& Seel, D. (2016). Penis envy and the female oedipus complex: A plea to reawaken an ineffectual debate. Psychoanalytic Review, 103(3), 397-421. https://doi.org/10.1521/ prev.2016.103.3.397 